\title{
Akut Lenfoblastik Lösemili Çocuklarda İdame Tedavisinin Nadir Bir Komplikasyonu: Folik Asit Eksikliği
}

\section{A Rare Complication of Maintenance Therapy in Children with Acute Lymphoblastic Leukemia: Folic Acid Deficiency}

\author{
${ }^{1}$ Mustafa BÜYÜKAVCI, ${ }^{2}$ Olena ERKUN, ${ }^{2}$ Ayşegül PALA, ${ }^{1}$ Mehmet Fatih ORHAN \\ ${ }^{1}$ Sakarya Üniversitesi Tıp Fakültesi, Sakarya Üniversitesi Eğitim ve Araştırma Hastanesi, Çocuk Hematoloji ve Onkoloji Bölümü, \\ Sakarya, Türkiye \\ ${ }^{2}$ Sakarya Üniversitesi Eğitim ve Araştırma Hastanesi, Çocuk Sağlı̆̆ı ve Hastalıkları Bölümü, Sakarya, Türkiye
}

\author{
Mustafa Büyükavc1: https://orcid.org/0000-0002-9054-3134 \\ Olena Erkun: https://orcid.org/0000-0003-3067-3794 \\ Ayşegül Pala: https://orcid.org/0000-0001-9056-144X \\ Mehmet Fatih Orhan: https://orcid.org/0000-0001-8081-6760
}

\section{ÖZ}

Vitamin B12 (Kobalamin) ve folik asit; DNA yapımında, hücre bölünmesi ve çoğalmasında rol alan ve eksikliğinde hematopoetik, sinir ve sindirim sisteminde ciddi hastalıklara yol açabilen vitaminlerdir. Akut Lenfoblastik Lösemi (ALL) nedeniyle idame tedavisi (metotreksat, 6merkaptopurin) alan 14 yaşında kız hasta solukluk ve burun kanaması şikâyetiyle kliniğimize başvurduğunda beyaz kan hücresi (white blood cells, WBC): 2230/ $\mathrm{mm}^{3}$, hemoglobin: 6,2 gr/dL, ortalama korpüsküler hacmi (mean corpuscular volume, MCV): $122 \mathrm{fL}$ ve trombosit: 26700 / $\mathrm{mm}^{3}$ idi. Periferik yaymasında hipersegmente nötrofiller, makrositer eritrositler, belirgin anizositoz, nadir normoblast ve her sahada 4-5 trombosit izlendi. Relaps ALL, aplastik kriz, megaloblastik anemi, hemofagositik lenfohistiyositoz (HLH) ve miyelodisplastik sendrom (MDS) ön tanılarıyla yatırılan hastanın kemik iliği aspirasyonbiyopsi değerlendirmesi sonucunda relaps olmadığı anlaşıldı. Başvuru sırasında istenen Vitamin B12 $587 \mathrm{pg} / \mathrm{mL}$, folik asit $1,3 \mathrm{ng} / \mathrm{mL}$ ve homosistein $21 \mu \mathrm{mol} / \mathrm{L}$ saptanmas1 üzerine Vitamin B12 ve folik asit tedavisi başland. ALL'li çocuklarda idame tedavisinde folik asit eksikliği gelişebileceği unutulmamalı ve açıklanamayan pansitopeni varlığında serum kobalamin ve folik asit düzeyi bakılmalıdir.

Anahtar Kelimeler: Anemi, folik asit, lösemi, pansitopeni

\section{ABSTRACT}

Vitamin B12 (cobalamin) and folic acid play a crucial role in DNA synthesis, cell division and proliferation. Their deficiency may cause serious disorders of hematopoietic, gastrointestinal and neurologic system. A 14-year-old girl, undergoing maintenance chemotherapy (methotrexate, 6mercaptopurine) for acute lymphoblastic leukemia (ALL), presented with the complaints of pallor and nose bleeding. At admission, white blood cells (WBC) was $2230 / \mathrm{mm}^{3}$, hemoglobin $6.2 \mathrm{gr} / \mathrm{dL}$, mean corpuscular volume (MCV) $122 \mathrm{fL}$ and thrombocytes $26700 / \mathrm{mm}^{3}$. Peripheral blood smear revealed hypersegmented neutrophils, macrocytosis, anisocytosis, rare normoblasts and 4-5 platelet per field. Bone marrow aspiration and biopsy did not confirm the pre-diagnoses of relapsed ALL, hemophagocytic lymphohistiocytosis (HLH) and myelodysplastic syndrome (MDS). Vitamin B12 and folic acid were prescribed after obtaining the results of vitamin B12 $(587 \mathrm{pg} / \mathrm{mL})$, folic acid $(1.3 \mathrm{ng} / \mathrm{mL})$ and homocystein $(21 \mu \mathrm{mol} / \mathrm{L})$. Folic acid deficiency must be kept in mind in childrenwith ALL receiving maintenance therapy. Serum cobalamin and folic acid levels must be checked in case of unexplained pancytopenia.

Keywords: Anemia, leukemia, folic acid, pancytopenia

Sorumlu Yazar / Corresponding Author:

Olena ERKUN

Yayın Bilgisi / Article Info:

Gönderi Tarihi/ Received: 27/05/2020

Sakarya Üniversitesi Tıp Fakültesi, Sakarya Üniversitesi Eğitim ve Kabul Tarihi/ Accepted: 24/10/2020

Araştırma Hastanesi, Çocuk Sağlığı ve Hastalıkları Bölümü, 54100, Online Yayın Tarihi/ Published: 30/12/2020

Sakarya, Türkiye

Tel: +90 5394851947 / +90(264) 4445400

Fax: +90 (264) 2759192

E-mail: elena.baluka@gmail.com

Atıf/ Cited: Büyükavcı M, et al. Akut Lenfoblastik Lösemili Çocuklarda İdame Tedavisinin Nadir Bir Komplikasyonu: Folik Asit Eksikliği. Online Türk Sağlık Bilimleri Dergisi 2020;5(4):701-704. doi: 10.26453/otjhs.742731 


\section{GíRiş}

Vitamin B12 (kobalamin olarak da adlandırılır), et, yumurta ve süt ürünleri dahil olmak üzere birçok hayvansal ürünlerde bulunur. ${ }^{1}$ Birçok bitki ve hayvan bazlı gıdada çeşitli folik asit formları (B9 vitamini de denir) bulunur. Vitamin B12 ve folik asit, DNA ve RNA sentezi için gerekli olan metilasyon reaksiyonları ve tek karbon transferlerinin yanı sıra gen metilasyonu ve nöronal miyelinizasyon için önemli proteinlerde kritik bir rol oynar. ${ }^{2}$ Vitamin B12 eksikliğinin yaygın nedenleri arasında pernisiyöz anemi (PA; intrensek faktöre [IF] karşı gelişmiş otoantikorlara bağlı bozulmuş emilim) ve gıda kobalamin malabsorbsiyonu (azalmış mide asiditesi, ilaçlar, pankreatik disfonksiyon ve/veya ince bağırsağı etkileyen bozukluklar) bulunur. Dengeli ve sağlıklı bir diyet tüketen kişide, folik asit eksikliği nadirdir. Ancak yetersiz beslenme veya kısıtlı diyetler, bağırsak malabsorpsiyon sendromları, bazı ilaçlar ve nadiren genetik bozukluklar gibi durumlarda görülebilir. ${ }^{3}$ Akut lenfoblastik lösemi tanılı çocuklarda da idame tedavisi sırasında metotreksat (MTX)'ın yan etkisi olarak folik asit eksikliği ortaya çıkabilir. ${ }^{4}$

$\mathrm{Bu}$ olgu sunumunda, ALL tanısıyla idame kemoterapisi aldığı sırada halsizlik ve burun kanaması nedeniyle kliniğimize başvuran ve pansitopeni tespit edilen bir hastamızın etyolojisinde folik asit eksikliği saptadığımızı belirterek konunun önemini vurgulamayı amaçladık.

\section{OLGU SUNUMU}

Olgu sunumu için hastanın kendi rızası ve ailesinin rızası alındı. Ayrıca hasta 18 yaşından küçük olduğundan hastanın velisine bilgilendirilmiş gönüllü olur onam formu imzalatıld.

ALL nedeniyle 15 aydır idame tedavisi (metotreksat ve 6-merkaptopurin) alan 14 yaşında kız hasta solukluk, yorgunluk, ara ara burun kanaması olması şikâyetiyle kliniğimize başvurdu. Genel durumu iyi, vücut ağırlığ $102 \mathrm{~kg}$ (>97 persentil) ve boyu $164 \mathrm{~cm}$ (50-75 persentil) idi. Daha önce geçirmiş olduğu Guillain-Barre sendromu nedeniyle desteksiz yürüyemeyen hastanın cilt ve mukozaları soluk olup diğer sistemik muayeneleri doğal idi. Laboratuvarında WBC: $2230 / \mathrm{mm}^{3}$, ANS: $1280 / \mathrm{mm}^{3}$, hemoglobin: 6,2 g/dl, MCV: 122 fL, MCH: 43,7pg, MCHC: 35,6 g/ dl, RDW: $\% 27,1$, retikülosit sayısı: $\% 5$, direkt coombs: negatif ve trombosit: $26700 / \mathrm{mm}^{3}$ saptand1. Periferik yaymada $\% 60$ nötrofil ve $\% 40$ lenfosit olup hipersegmente nötrofiller, makrositer eritrositler, belirgin anizositoz, nadir normoblast ve her sahada 4 -5 trombosit izlendi. Relaps ALL, aplastik kriz, me- galoblastik anemi, HLH ve MDS ön tanılarıyla yat1rıld1. Derin anemisi ve tekrarlayan burun kanamaları nedeniyle 3 ünite eritrosit süspansiyonu ve 1 ünite trombosit süspansiyonu verildi. Olgunun başvuru sirasında istenen Vitamin B12: 587 pg/mL (200-800 $\mathrm{pg} / \mathrm{mL}$ ), folik asit: $1,3 \mathrm{ng} / \mathrm{mL}$, homosistein: $21 \mu \mathrm{mol} /$ L, fibrinojen: $250 \mathrm{mg} / \mathrm{dL}$, ferritin: $4541 \mathrm{ng} / \mathrm{mL}$, laktatdehidrogenaz (LDH): $427 \mathrm{U} / \mathrm{L}$, trigliserid: $88 \mathrm{mg} /$ dL, total kolesterol: $157 \mathrm{mg} / \mathrm{dL}$, HDL kolesterol: 60 $\mathrm{mg} / \mathrm{dL}$ ve LDL kolesterol: 93mg/dLsaptand.

Yapılan kemik iliği aspirasyon yayması heterojen ve normosellüler olarak değerlendirildi. Atipik hücre gözlenmezken miyeloid seri $\% 60$, eritroid seri $\% 30$ ve lenfoid seri \%10 olarak saptand. Ayrica eritroid seri hücrelerinin bir kısmında lobüle çekirdekler ve sitoplazmik inklüzyon cisimcikleriyle birlikte çok nadir olarak hemofagositoz gözlendi. Kemik iliğinden yapılan flow sitometri çalışmasında da normal dağılım olup blast gözlenmedi. Kemik iliği biyopsi sonucu; normosellüler kemik iliği, miyeloid seride hipersegmente nötrofiller, eritroid seri kesintisiz matürasyonlu kolonizasyon, çift nükleuslu ve perinükleer tomurcuklanma gösteren eritroblastlar, eritroid seri/granülosit seri oranı: 1/10 ve megakaryositer seri normal olarak rapor edildi. Bu bulgularla megaloblastik anemi düşünülen hastaya Vitamin B12yle (1000 mcg/gün, iki doz intramuskuler sonra oral) birlikte oral folik asit (10 mg/gün oral) tedavisi başlandı. Bu sırada hemoglobin: $9,4 \mathrm{~g} / \mathrm{dL}$, WBC: $2140 / \mathrm{mm}^{3}$ ve trombosit: $56500 / \mathrm{mm}^{3}$ idi. Folik asit tedavisinin 7. gününde hemoglobin: $9,3 \mathrm{~g} / \mathrm{dL}$, WBC: $3950 / \mathrm{mm}^{3}$ ve trombosit: $104000 / \mathrm{mm}^{3}$ saptandi. Tedavinin 15. gününde hemoglobin: $12,3 \mathrm{~g} / \mathrm{dL}$ ve trombosit: $247000 / \mathrm{mm}^{3}$ 'e; 30 . gününde hemoglobin: 14,3g/dL'ye yükselerek normale döndü. Folik asit suplementasyonu sırasında idame kemoterapisi de sürdürülen hastanın halen oral Vitamin B12 ve folik asit ( $5 \mathrm{mg} /$ gün) tedavisine devam edilmektedir.

\section{TARTIŞMA VE SONUÇ}

Megaloblastik anemi (MA), megaloblast adı verilen büyük kırmızı kan hücresi öncüllerinin kemik iliğindeki varlığı ile karakterize heterojen bir anemi grubunu kapsar. Bu durum, nükleer bölünmeyi engelleyen bozulmuş DNA sentezinden kaynaklanmaktadır. Esas olarak RNA ve protein sentezine bağlı sitoplazmik olgunlaşma daha az bozulmaktadır; bu, megaloblastların büyük boyutunu açıklayan eritroblastların çekirdeği ve sitoplazması arasında asenkron bir olgunlaşmaya yol açar. Makrositoz ve hipersegmente nötrofillerin bulunması kobalamin ya da folik asit eksikliği tanısı açısından şüphelenilmesi gereken bir 
durumdur. $^{5}$ Kobalamin ve folik asit eksikliğinde 'inefektif' eritropoez izlenir. Kemik iliği öncül hücreleri kemik iliğinde aktif olarak üretilir, kemik iliği hipersellüler hale gelir, ancak genellikle retikülosit sayısı artmaz. İntramedüller apoptozisin göstergesi olarak serum LDH artışıyla birlikte hiperbilirubinemi gelişebilir. Megaloblastik anemide 'inefektif' eritropoez sonucu serum demir ve ferritin düzeyleri artar ve ayrıca anemi derinleştikçe trombositopeni ve nötropeni de görülebilir.

Vitamin B12 ve folik asit eksikliği, çocukluk çağ megaloblastik anemilerinin en sik nedenidir. Megaloblastik anemi; malnütrisyondan ve bazı ilaçlardan (metotreksat, metformin, 6-merkaptopurin, trimetoprim) kaynaklanabilir. Olgumuz da 15 aydır metotreksat ve 6- merkaptopurinle aralıklı olarak trimetop$\mathrm{rim} /$ sulfametoksazol tedavileri almaktaydı. Bu ilaçların yan etkisi olarak sıklıkla trombositopeni ve lökopeni görülebilmektedir. Bu nedenle de idame tedavisi alan ALL hastasının takibinde her ay hemogram kontrolü yapılmakta ve değerlere göre ilaç dozları ayarlanmaktadır. Bir ay önceki tam kan sayımı değerleri normal olan hastamızda pansitopeni gelişmesi üzerine öncelikle relaps olabileceği düşünülerek yatırıldı ve MDS, aplastik kriz, HLH ve kobalaminfolik asit eksikliği açısından ayırıcı tanı yapılmak üzere tetkikleri alındı. Ferritin düzeyi aylardır yüksek seyreden hastanın pansitopenisi olmasına karşın; ateşi ve splenomegalisi olmaması, trigliserid ve fibrinojen seviyelerinin normal olması ve kemik iliği incelemesinde blast ve belirgin hemofagositoz saptanmaması üzerine relaps ALL ve HLH tanıları ekarte edildi. Retikülosit düzeyi (\%5) ve kemik iliği biyopsisi değerlendirmesi de aplastik anemi ve MDS tanılarıyla uyumlu değildi. Periferik yaymada makrositoz, anizositoz ve hipersegmente nötrofil varl1ğıla birlikte folik asit düzeyi düşük olan hasta megaloblastik anemi olarak değerlendirildi.

Serum kobalamin ölçümünün $<200 \mathrm{pg} / \mathrm{mL}$ ve folik asit $<2 \mathrm{ng} / \mathrm{mL}$ olan bireylerde Vitamin B12 ve folik asit eksikliği tanısı konulur. Vitamin B12 seviyesi sınırda düşük veya klinik tablo ile uyumsuz ise metilmalonik asit (MMA), homosistein ve/veya IF veya gastrik parietal hücre antijenlerine karşı otoantikorlarla ek test yapılması uygun olabilir. ${ }^{6}$ MMA ve homosistein düzeyleri kobalamin ve folik asit eksikliği tanısı koymak için yardımcı göstergelerdir. ${ }^{7}$ Kobalamin eksikliğinde hem MMA hem de homosistein artarken, folik asit eksikliğinde sadece homosistein artar. Olgumuzda kobalamin seviyesi normal, folik asit değeri 1,3 ng/mL ile düşük ve homosistein seviyesi yüksek olması üzerine Vitamin B12 ve folik asit tedavisi başlandı. Folik asit tedavisi hızlı hematolojik yanıt vermesine rağmen kobalamin eksikliğine bağlı nörolojik bulguları artırabildiğinden dolayı önce kobalamin tedavisi başlanmaktadır. Megaloblastik anemi tedavisinde kullanılabilen birçok formülasyon ve olası uygulama yolları vardır. Vitamin B12 eksikliği oral veya parenteral Vitamin B12 ile tedavi edilebilir. ${ }^{6}$ Folik asit eksikliği ise tipik olarak oral folik asit ile tedavi edilir (günde $5-40 \mathrm{mg}$ ). ${ }^{7}$

Folik asit eksikliğinin MTX metabolizması ve sitotoksisite üzerindeki etkilerine dair literatürde çalışmalar mevcuttur. Folik asit desteği MTX tedavisinin yan etkisini azaltmakla birlikte kemoterapinin etkinliğini azaltma konusunda da endişeler doğurmuştur. ${ }^{8}$ Schroder ve ark. idame tedavisi sirasinda verilen folik asit suplementasyonunun kemik iliğinin proliferatif kapasitesini arttırdığını, ancak suplementasyon yapılmayan grupta eritrosit folik asit düzeyinin normal olduğunu, bu yüzden de MTX tedavisi ile beraber folik asit desteğine gerek olmadığını bildirmişlerdir. ${ }^{9}$ Diğer yandan, idame tedavisi alan ve folik asit eksikliği olan ALL tanılı çocuklarda nötropeni ve trombositopeni gibi tedaviye bağl1 komplikasyonların yaygın olup bazı çocuklarda kemoterapi dozunun azaltılmasını gerektirdiğini belirten çalışmalar da bulunmaktadır. ${ }^{4}$ Kennedy ve arkadaşları da folik asit desteği ve MTX tedavisi arasındaki bağlantıyı araştırmışlar ve folik asit tedavisinin idame tedavisi alan ALL'li çocuklarda herhangi bir olumsuzluğa yol açmadığını belirtmişlerdir. ${ }^{10}$

Akut lenfoblastik lösemili çocuklarda idame tedavisi sırasında folik asit eksikliği gelişebileceği akılda tutulmalı ve açıklanamayan pansitopeni varlığında serum kobalamin ve folik asit düzeyi kontrol edilmelidir.

Etik Komite Onayı: Bu çalışma için etik kurul iznine gerek yoktur. Bebeğin annesinden sözlü ve yazılı onam alınmıştır.

Çıkar Çatışması: Yazarlar çıkar çatışması bildirmemişlerdir.

Yazar Katkıları: Fikir-NÇ, ÖT; Denetleme-NÇ, İC; Malzemeler- IC, ÖT; Veri toplanması ve/veya işlemesi- ÖT, İC; Analiz ve/veya yorum-NÇ, İC, ÖT; Yazıyı yazan- NÇ, İC, ÖT

Hakem değerlendirmesi: Dış bağımsız

\section{KAYNAKLAR}

1. U.S. National Institutes of Health. Vitamin B12. 2020.https://ods.od.nih.gov/factsheets/ VitaminB12HealthProfessional/. Erişim tarihi 
29 Haziran 2020.

2. Green R. Vitamin B12 deficiency from the perspective of a practicing hematologist. Blood. 2017;129(19):2603-2611.

3. Qiu A, Jansen M, Sakaris A, et al. Identification of an Intestinal Folate Transporter and the Molecular Basis for Hereditary Folate Malabsorption. Cell. 2006;127(5):917-928.

4. Roy Moulik N, Kumar A, Agrawal S, Mahdi AA. Folate deficiency in north Indian children undergoing maintenance chemotherapy for acute lymphoblastic leukemia-Implications and outcome. Pediatr Blood Cancer. 2018;65(1). doi: $10.1002 /$ pbc. 26730

5. Socha DS, DeSouza SI, Flagg A, Sekeres M, Rogers HJ. Severe megaloblastic anemia: Vitamin deficiency and other causes. Cleve Clin J Med. 2020;87(3):153-164.

6. Devalia V, Hamilton MS, Molloy AM. Guidelines for the diagnosis and treatment of cobalamin and folate disorders. $\mathrm{Br} \mathrm{J}$ Haematol. 2014;166(4):496-513.

7. Lanzkowsky P. Chapter 7 -Megaloblastic Anemia. In: Lanzkowsky P, Lipton JM, Fish JD, Editors Lanzkowsky's Manual of Pediatric Hematology and Oncology. 6th Edition. Academic Press: San Diego. 2016:32-41.

8. Robien K. Folate during antifolate chemotherapy: what we know... and do not know. Nutr Clin Pract. 2005;20(4):411-422.

9. Schrøder H, Clausen N, Ostergård E, Pressler T. Folic acid supplements in vitamin tablets: a determinant of hematological drug tolerance in maintenance therapy of childhood acute lymphoblastic leukemia. Pediatr Hematol Oncol. 1986;3(3):241-247.

10. Kennedy DA, Grupp S, Greenberg M, Koren G. Folate fortification and survival ofchildren with acute lymphoblastic leukemia. Pediatr Drugs. 2011;1;13(3):193-196. 